\title{
Analysis of Back-End Requirements of a Web-Based Applieation to Identify Damage for Building Structures
}

\author{
Anisyal and Fajar Nugroho ${ }^{2}$ \\ ${ }^{1,2}$ Institut Teknologi Padang \\ anisya@itp.ac.id ${ }^{1}$, fajarnugroho@itp.ac.id ${ }^{2}$
}

\begin{abstract}
The need for well-maintained facilities can certainly affect activities in the building. To meet these needs, a building maintenance work program is needed to achieve the planned life of the building. The problem with contractors is that they still use telephone communication to receive reports of any damage to the building. This paper discusses the needs analysis in the construction of a building damage reporting system from the backend side. The application is built on a web-based basis and provides information about the building in terms of the structural aspect as well as grouping the damage based on the damage criteria. The results of this study are obtained in the form of 10 tables that will compile a system database and transaction analysis that can be done in the system, namely generating building damage data reports where there are four categories of damage, namely light damage, moderate damage, severe damage, total damage and this application can later be used by building managers in reporting building damage through applications and contractors can monitor through applications.
\end{abstract}

Keywords: back-end, web-based, structure damage, identify

\section{Introduction}

Building is a physical form resulting from construction work that is integrated with its domicile, partially or wholly located above and/or in the land and/or water, which functions as a place for humans to carry out their activities, either for housing or residence, religious activities, business, social, cultural, or special activities, so that the building needs to be maintained so that the building is able to stand well in the long term. As stated in the Regulation of the Minister of Public Works No : 16/PRT/M/2010 CONCERNING TECHNICAL GUIDELINES FOR PERIODIC BUILDING INSPECTIONS, every building in Indonesia must be regularly maintained/inspected [1]. The aspects that need to be considered in building maintenance are aspects of architecture, structure, mechanical, electrical, outdoor layout, and housekeeping. economical. Overall the building structure consists of two parts, namely the upper structure in the form of floors, beams, columns, walls and roofs, while the lower structure consists of foundations and sloof beams [2]. A building defect is a failure or mistake that reduces the value of the building and may cause a dangerous condition to the user's if neglected building. A defect may arise from some carious factors such as poor workmanship, design fault, wrong selection of material and so on. Building defects will result in various implications [3]. It may reflect the negligence occurred, and also illustrates the lack of concern on problems arising from the construction work on the building as well as building refurbishment. A defect may be considered to be failing or unsatisfactory in the functional performance, user or statutory requirements of a building and might manifest itself within the fabric, structure, services and facilities of the affected to the building [4].

Ransom states that despite calls for closer integration of design and construction, the role remains essentially separate [5] This paper shows that more than 90\% of building defects can be explained partially or completely as a result of easily identifiable design 


\section{Cisinta}

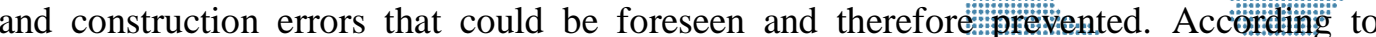
Hardianto [6] maintenance activities are not given much attention exte to several factors. These factors include: (1) Maintenance activities are seen as wo urgent compared" to development activities. (2) Improper maintenance organizational structure. (3) The activity manager assumes that the maintenance of the building is a technical matter alone, not related to the purpose of the building's function according to the wishes of the user. In previous studies that have been carried out, discussing the design of the building damage reporting system that may occur in the observed building and compiling technical reporting that will be carried out by building managers in contacting the party responsible for the damage [7]. However, in this paper, the researcher discusses the continuation of the previous problem, namely the need from the back-end side of the web-based system to be built.

\section{Research Methodology}

In writing this paper, the author designs the needs from the back-end side of a Webbased building damage reporting application. This type of research is experimental, by testing the use of applications in buildings for recording reports of building damage and classifying damage based on damage criteria.

There are several methods to obtain the required data, including:

a. Library Studies

Looking for reference books that can help provide information and understanding of the basic concepts of building maintenance and maintenance.

b. Observation (Observation)

The data obtained is the result of direct observation of similar applications that provide input on building damage and direct data retrieval of each building.

\section{Result and Discussion}

\subsection{Context Diagram}

Context Diagram is a general description of showing the boundaries of the external system entity with the system and as a tool for global system design that shows the system and its parts in general.

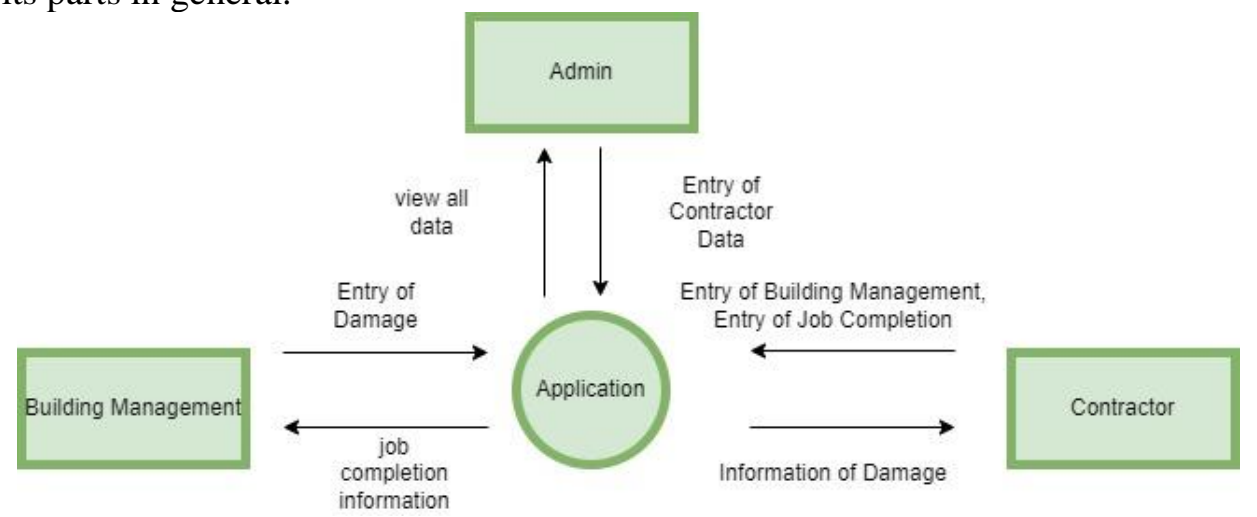

Figure 1. Context Diagram

\subsection{Cases}

a) In the meeting room of building $\mathrm{A}$, there is subtle damage to the stucco smaller than $0.075 \mathrm{~cm}$, stucco fragments fall, and covers a limited area.

b) In the hall of building B, there are small cracks in the width of the gap between 0.075 to $0.60 \mathrm{~cm}$ on the wall, the plaster is loose and falling off, covering a large area, damaged parts of the chimney and lip tank, and is fit for function / habitation.

c) In the toilet of building $C$ there is a large crack damage of more than $0.60 \mathrm{~cm}$ on the wall, the cracks are widespread in many places, such as in (walls, load bearings, 


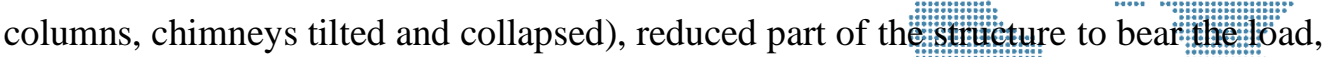
and the fit function / occupancy

d) In building D there is heavy damage, the building collapses $\$ 9 \%$, the loadibearing wall splits and collapses, the main element is thought to be damaged and unfit for function / habitation

e) In building $\mathrm{E}$ there is total damage to the building falling $>65 \%$, most of the main components of the structure are damaged and the building is not fit for function / habitability.

Table 1. Damage Category

\begin{tabular}{|c|c|c|}
\hline No & Category & Description \\
\hline 1. & \multirow{3}{*}{ Non-Structure Minor Damage } & $\begin{array}{l}\text { Fine cracks (more gaps smaller than } 0.075 \mathrm{~cm} \text { ) in } \\
\text { plastering }\end{array}$ \\
\hline 1.1 & & Plaster flakes falling \\
\hline 1.2 & & Covers a limited area \\
\hline 2. & \multirow{5}{*}{ Slight Damage to Structure } & $\begin{array}{l}\text { Small cracks (gap width between } 0.075 \text { to } 0.60 \text { ) in } \\
\text { the wall }\end{array}$ \\
\hline 2.1 & & Plaster comes off and falls off \\
\hline 2.2 & & Covers a large area \\
\hline 2.3 & & $\begin{array}{c}\text { Damage to non-structural parts such as the } \\
\text { chimney, etc. }\end{array}$ \\
\hline 2.4 & & Suitable for function / occupancy \\
\hline 3. & \multirow{4}{*}{ Moderate Structural Damage } & $\begin{array}{l}\text { Large cracks (gap width greater than } 0.60 \mathrm{~cm} \text { ) in } \\
\text { walls }\end{array}$ \\
\hline 3.1 & & $\begin{array}{c}\text { Cracks are widespread in many places, such as in } \\
\text { load-bearing walls, columns, chimneys tilt and } \\
\text { collapse }\end{array}$ \\
\hline 3.2 & & $\begin{array}{l}\text { The ability of the structure to bear the load has } \\
\text { been partially reduced }\end{array}$ \\
\hline 3.3 & & Suitable for function / occupancy \\
\hline 4. & \multirow{4}{*}{ Heavy Structure Damage } & The load-bearing wall splits and collapses \\
\hline 4.1 & & $\begin{array}{l}\text { Building separated due to failure of fastening } \\
\text { elements }\end{array}$ \\
\hline 4.2 & & $\begin{array}{c}\text { Approximately } 50 \% \text { of the main elements are } \\
\text { damaged }\end{array}$ \\
\hline 4.3 & & Not fit for function / occupancy \\
\hline 5. & \multirow{3}{*}{ Overall damage } & Building completely collapsed (>65\%) \\
\hline 5.1 & & $\begin{array}{c}\text { Most of the main components of the structure are } \\
\text { damaged }\end{array}$ \\
\hline 5.2 & & Not fit for function / occupancy \\
\hline
\end{tabular}

From the table that has been determined, the example case in the building above has the following output:

a) Building A suffered damage which was categorized as non-structural damage.

b) Building B suffered damage which was included in the Light Structure category.

c) Building $\mathrm{C}$ suffered damage which was categorized as Medium Structure.

d) Building D suffered damage which was categorized as Heavy Structure damage.

\subsection{Entity Relationship Diagram (ERD)}

Entity Relationship Diagram (ERD) is a chart depicting a database design tool, which consists of real objects. Entity Relational Diagram (ERD) can help in studying the relationship between database files to be designed. From the Normalization process to 3 $\mathrm{NF}, \mathrm{ERD}$ is obtained as shown figure 2. 


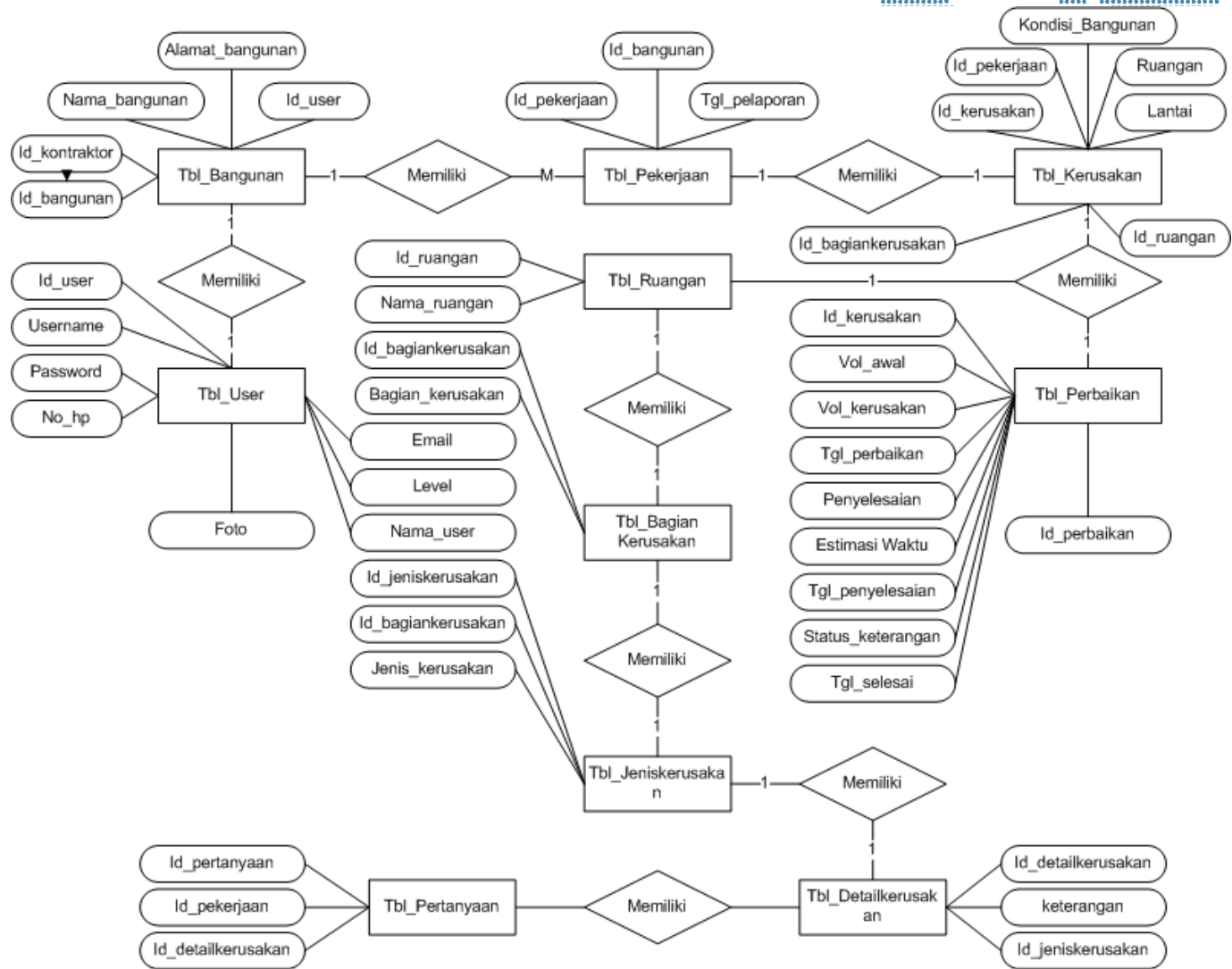

Figure 2. Entity Relationship Diagram (ERD)

\section{Conclusion}

In the construction of a building damage reporting system, a needs analysis from the back-end side is needed, one of which is the need for transaction processing between the user interface and data storage. there will be 5 types of damage to buildings from the structural side and the number of user levels who will use this system is 3 people.

\section{References}

[1] PermenPU, "Menteri pekerjaan umum," pp. 1-17, 2010.

[2] K. Tuban, D. Nugroho, A. A. Saputra, and D. A. Cahyono, "Analisis Balok dan Kolom Struktur Beton ( Studi kasus café di J1 . Manunggal , Desa Gedongombo , Kecamatan," vol. 09, pp. 1-15, 2020.

[3] M. A. Othuman Mydin, N. A. Agus Salim, S. W. Tan, N. M. Tawil, and N. M. Ulang, "Assessment of Significant Causes to School Building Defects," E3S Web Conf., vol. 3, pp. 1-7, 2014, doi: 10.1051/e3sconf/20140301002.

[4] David S. Watt, Review of Building Pathology: Principles and Practice, vol. 18, no. 2. 2008.

[5] J. Douglas and B. Ransom, Understanding building failures: Third edition, vol. 1, no. 1.2007.

[6] W. Hardianto, A. B. Hanintyo, H. Indarto, and I. Nurhuda, "Perencanaan Struktur Gedung Kuliah di Yogyakart,” J. Karya Tek. Sipil, vol. 3, pp. 1056-1068, 2014.

[7] A. Anisya and F. Nugroho, "Design of structural damage identification applications web-based," MATEC Web Conf., vol. 215, 2018, doi: $10.1051 /$ matecconf/201821501032. 

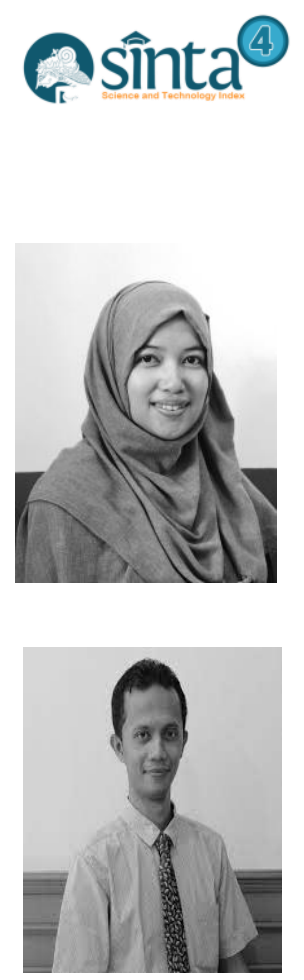

International Joưumatof of

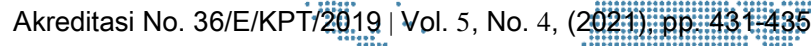

\section{Authors}

Anisya, actively teaching since 2013 in: the department of informatics engineering at the Padang Institute of Technology, with a research focus on web-based applications and machine learning.

Fajar Nugroho, active majoring in vocational civil engineering at the Padang Institute of Technology, with a research focus on structure buildings 